\title{
Covid-19, Congregational Worship, and Contestation over 'Correct' Islam in South Africa
}

\author{
Goolam Vahed \\ vahedg@ukzn.ac.za
}

\section{Abstract}

In response to the global Coronavirus pandemic, South African President, Cyril Ramaphosa declared a national lockdown on March 26, 2020, which suspended, among other things, congregational worship. A group of Muslims made an urgent court application for permission to pray in mosques, which was dismissed on April 30, 2020, with the judiciary weighing in on the side of the public health good. This struggle over congregational prayers brought into the open, differences among Muslims in South Africa that have been simmering for several decades and raised questions as to how to balance the post-apartheid Constitution's accommodation of religious practices with the needs of a secular state ${ }^{1}$. Conversely, what should Muslims do when they are required to follow the secular rules of a non-Muslim country that contradict their obligations to the tenets of their faith? The court case underlined the deep divides amongst Muslims and the changing structures of authority. In the absence of a central doctrinal authority the Ulama terrain is highly competitive and fraught with antagonistic doctrinal differences. It remains to be seen whether these divisions will boil over into physical confrontation among Muslims, and, with trust in the state dissipating, how Muslims will manage their relationship with the secular state.

1 This article acknowledges the assertion of Schoeman (2017:6 of 7) that it is debatable whether South Africa can be strictly regarded as a secular country. While the vast majority of people claim to be Christian, the extent to which they adhere strictly to Christianity is debatable. 


\section{Goolam Vahed}

Keywords: Covid-19, Mosque closure, UUCSA, Majlis, Cyril Ramaphosa, Zehir Omar, Ebrahim Rasool, Wifaq

\section{Introduction}

In response to the global Coronavirus pandemic (Covid-19), South African President, Cyril Ramaphosa declared a state of disaster on March 15, 2020. A week later, he announced a three-week nationwide lockdown from midnight on Thursday, March 26, 2020. With the exception of those involved in providing 'essential services', all South Africans were required to stay at home. Congregational attendance at places of worship was prohibited.

Following the president's announcement, a prominent Durban Mufti ${ }^{2}$ called on Muslims to continue to pray in mosques in defiance of the law. On Friday, April 3, 2020, police cracked down on several mosques in KwaZuluNatal, following the afternoon prayer. The Majlisul Ulama of South Africa (MUSA) and Jamiatul Ulama of South Africa (JUSA) ${ }^{3}$ wrote to the presidency on April 4, 2020, requiring permission to offer prayers in mosques. The request was declined on April 9, 2020. Muhammed Bin Hassim Mohamed, Anas Mohammed Chothia, and the As-Saadiqeen Islamic Centre from Gauteng, understood to be aligned to MUSA, made an urgent application to the High Court in Pretoria for permission to pray in mosques. Another Muslim organization, the United Ulama Council of South Africa (UUCSA) ${ }^{4}$, applied

2 This is a jurisconsult - a Muslim legal expert qualified to give rulings on religious matters.

3 MUSA is a Port Elizabeth-based organization under Moulana Desai. A search for 'JUSA' leads to the website of the Jamiatul Ulama South Africa, a Fordsburgbased organization under the leadership of Moulana Ebrahim Bham, whereas the group who submitted the letter to the President was the Jamiatul Ulama Gauteng, which is based in De Deur. The organization is unlikely to have made a mistake with its own name, and this is likely an indication that they are contesting ownership of JUSA while also attempting to confuse the public as to the drafters of the letter, since Moulana Bham was in favor of mosque closure.

4 UUCSA is an umbrella body formed in 1994 to bring together different Ulama formations with the aim of working in unison to meet the challenges facing Muslims under the new non-racial democratic dispensation. Its members include the Muslim Judicial Council (SA), Jamiatul Ulama South Africa, Jamiatul Ulama 
to be an amicus curiae (literally 'friend of the court'), essentially offering the court information in support of the government's decision. On April 30, 2020, the application of Muhammed Bin Hassim Mohamed, Anas Mohammed Chothia, and the As-Saadiqeen Islamic Centre was dismissed by the Pretoria High Court.

This court application provides a lens through which to examine two broad issues with regard to Muslim South Africans, namely, what it means to live as a Muslim in a secular democracy, and the structures of religious authority among Muslims. Ulama have long debated what it means to be a Muslim minority in a secular democracy. Are Muslims permitted to reside as minorities in a majority non-Muslim country? What should they do when they are required to obey laws that contradict their obligations to shari'ah? More specifically, in a South African context, how does the state balance the post-apartheid Constitution's accommodation of religious practices with the needs of a secular state? What challenges will the new forms of religiosity, evident among South Africa's Muslims, present to the state? This article also examines the changing structures of authority among Muslims, caused in particular by their reactions to the pandemic.

\section{Contesting Authority}

This article is based on newspaper reports, the records of the court case being referred to in this article, the correspondence of Muslim organizations, and the messages sent via internet communication tools such as e-mails, chat applications like WhatsApp, Islamic radio and television channels, websites of Islamic organizations, blogs, and social media sites like Facebook and Twitter ${ }^{5}$. As Johannesburg-based attorney, Feroze Boda (2020), who represented Muhammed Bin Hassim Mohamed, Anas Mohammed Chothia, and the As-Saadiqeen Islamic Centre in the mosque court case, observed, these exchanges were mostly vitriolic: 'It is most disheartening to see the manner in which some people use social media, directly or indirectly, to pursue agendas that are narrow and could be interpreted as vilifying other

(KZN), Sunni Jamiatul Ulama, Sunni Ulama Council, Council of Ulama Eastern Cape, and Eastern Cape Islamic Congress.

5 Many of the documents and recordings quoted below were received via social media and are in the author's possession. 


\section{Goolam Vahed}

Muslims who have expressed differing opinions'. This applied equally to both sides.

The Muslim landscape in South Africa is extremely diverse and Islam is a minority religion. The General Household Survey of 2013 put the Muslim population at just over a million out of a total population of 52 million (Schoeman 2017:4 of 7 pages), although Muslims themselves believe that the number is closer to two million, as many migrants may not be accounted for. Muslims comprise of several streams: 'Malays' ${ }^{6}$, who are descendants of slaves from South and South-East Asia, who arrived in the Cape from the $17^{\text {th }}$ century and are concentrated in the Western Cape; the descendants of indentured migrants from South and North India who were brought to work on the sugar plantations of colonial Natal between 1860 and 1911; the free Indian migrants from Western India who followed in their wake and are concentrated in Gauteng and KwaZulu-Natal (Vahed 2021); post-apartheid migrants from South Asia and Africa (cf. Vawda 2017; Koch 2017); and a small indigenous African grouping (Sitoto 2014). Malay and Indian Muslims are roughly equal in numbers and, despite new migrations, still make up the majority of the Muslim population in South Africa and remain in control of most major institutions and mosques in the country.

Muslim beliefs and practices are fluid. As Afsaruddin (2015:1) points out, Islam and Muslim societies should not be 'presented as static and reified...[An] historical, diachronic approach allows the reader to see the evolutionary nature of Islamic thought and the diversity within it'. By the 1970s, there were three broad traditions among Muslims in South Africa: First, a popular one that paid homage to Pirs (guides), as intercessors between Muslims and God, who respected and visited their karamats (gravesites), and organized mouloods (religious gatherings) where salami (communal salutations) were offered to the Prophet and saints as a mark of respect; second, a reformist tradition that drew inspiration from late $19^{\text {th }}$-/early $20^{\text {th }}$-century Deobandi/ Tablighi traditions in North India, that placed emphasis on 'an unquestioning loyalty to a literal interpretation of Prophetic authority' and on the central

6 While accepting that race is a social construct, it has been and remains a legal and social fact in South Africa, where the population is divided into four racial groups: Black African, Colored, White, and Asian/Indian. Malays are categorized as Colored, while black and African are used in this article to refer to black Africans. 
role of the ulema in defining the correct practice of Islam, and which was highly critical of populist practices that were seen as remnants of Hinduism; and third, a 'modernist' tradition that attempted to combine Islamic with modern, secular knowledge in order to engage in discourse with the Western secular culture and thought (a good exemplar was the Muslim Youth Movement formed in 1971). These differences aroused deep passions, which flared into open conflict, particularly during the 1980s (cf. Tayob 1999; Jeppie 2007; Vahed 2003 for a discussion of these issues from an historical perspective).

Ulama (theologians or jurists trained in Muslim theology or Shari'ah - Muslim legal studies) are increasingly at the heart of shaping Muslim society through what they consider as the 'renewal' of traditional Islamic knowledge (Zaman 2010; Moosa 2015). This is also true in South Africa, where the influence of Ulama, which was historically very strong among Muslims in the Cape, has grown markedly since the 1970s, particularly among Indian Muslims, when locals returned from training in Indian seminaries, and especially from the 1980s when Darul Ulooms (Islamic seminaries), many of whose systems and syllabi are largely transplanted from South Asia, were opened. At the same time, the Madrassah system, which had long predated Darul Ulooms, expanded, was centralized, and adopted formal syllabi. In this respect, there appears to be an important difference with Bano's argument that in the West (or Muslim minority countries), there is a weakening of the authority of traditional Ulama among educated and upwardly mobile 'second- and third-generation Muslims...The current Islamic religious milieu in the West is highly conducive to nurturing an Islamic understanding which, while respecting the core of the Islamic tradition, is also proving adept at guiding young Muslims to be confident members of their respective societies' (Bano 2019:7).

In contrast, in the South African context, one can argue that many Muslims have moved from being comfortable in their societies to finding that the values of the secular state are challenging their changing understanding of Islam. Visible changes since the 1990s include Muslims attaching themselves to religious figures (shaykhs) for guidance, the growth of Islamic schools and finance, the adoption of 'Islamic' dress, men growing beards and women covering their faces (niqaab), girls not acquiring secular education, television sets being discarded, and more Muslims going on pilgrimage (cf. Vahed 2000). 


\section{Goolam Vahed}

While the influence of Ulama has increased, there is no central authority that all Muslims abide by. Ulama have become increasingly fragmented, with various individuals and organizations wielding influence through access to resources and control of media (cf. Tayob 2004). The Prophet was the authority while he was alive, but as Islam spread globally, ethnic and cultural differences as well as social, economic, and political contexts, shaped contestations within the realm of hermeneutics.

Two broad groupings were involved in the court case over the opening of mosques. One of the problems in writing this article is nomenclature. While there are many groupings and sub-groupings, broadly, those who argued for the opening of mosques have variously been called 'fundamentalists', 'conservatives', or 'regimentalists', while those who held a contrary view were in the past labelled as 'modernists' or 'liberals', but to that has been added epithets like 'pro-Shia' and 'anti-Ulama'. These terms are avoided in this article because they are value-laden and trivialize complex phenomena. Instead, this article refers to the groupings by their main protagonists. Those who wanted mosques to remain open are referred to as the Majlis/Mufti AK grouping while the UUCSA grouping refers to those who were willing to abide by government policy to temporarily prohibit congregational prayer in mosques.

The UUCSA was founded in 1994 at a meeting convened by Sheikh Nazim Mohamed, then Imam of the Yusufia Masjid Mosque in Wynberg, Cape Town, and life president of the Muslim Judicial Council (MJC), and formalized in 1996. Its logo, adopted in 1995, comprises a map of southern Africa with the geographical area of South Africa highlighted, upon which a crescent moon and a star are superimposed. Aimed at uniting the major theological formations in South Africa, UUCSA included members from across South Africa, of different Islamic traditions and practices, which had been at loggerheads in the 1970s and 1980s. Attacks on UUCSA are usually aimed at its executive member, Moulana Ibrahim Bham, most likely because of his public profile and location in Gauteng, where several Darul Ulooms are based. Moulana Bham completed his studies in Pakistan in the 1980s, and is Imam of the Hamidia Mosque in Newtown, Johannesburg and secretarygeneral of (the original) JUSA. His leading of the Muslim prayer at the Nelson Mandela Memorial Ceremony in 2013 and the performance of the prayer at struggle icon, Ahmed Kathrada's funeral in 2017, drew criticism from the Majlis, which sarcastically refers to him as 'the Reverend Abraham 
Bham'. UUCSA Ulama have access to radio channels - Radio Islam and Channel Islam International - and one television channel, ITV Networks, as well as various websites.

The Majlis is synonymous with Moulana Desai, who was born in Port Elizabeth (PE, now Gqeberha) and completed his theological education in Jalalabad, India, in the 1960s. He established MUSA in PE and started a monthly newspaper The Majlis. According to Haron, Moulana Desai and members of MUSA 'perceived themselves to be the gatekeepers of Islam and the representatives of a "pure, roohani Islam"" (Haron 2003:56; original emphasis). Ismail Omar of the House of Ummah (HOU) ${ }^{7}$ wrote that the Moulana...holds himself out to be the supreme guardian of the truth in South Africa, and in so doing, he often lambasts those that perceive the truth differently' (HOU 2020a). Moulana Desai's 'version of the truth [is presented as] natural...as if it were self-evident [as he] constructs an authoritative vision of things' (Dupret 2018:217).

There is no formal alignment between Mufti AK and the Majlis, but they support each other's positions on most issues. In one of his talks on the Markaz Sahaba radio station, Mufti AK described Moulana Desai as one of the ten greatest living Islamic jurists in the world. According to the biography on his website (Official Site of Mufti AK Hoosen 2018), Mufti AK completed his BA Hons (Mufti and Alim) in Pakistan, and obtained a Master's degree in Islamic Studies at the University of Johannesburg in 1990. He joined the Darul Uloom, Newcastle in 1980, and taught there until he took up a position with the Johannesburg-based Islamic radio station, Channel Islam International in 2000. He then established his own radio station, Markaz Sahaba in 2018, and still serves as Mufti and radio presenter. Mufti AK, as he is popularly known, has an extensive national and international following,

7 Ismail Omar is a lawyer by training, was involved in politics in the Tricameral Parliament in the 1980s and is now a businessperson. He is not involved in any Muslim organization, but in 2013, in response to an article by Moulana Desai that stated that Hassim Amla was an apostate for playing cricket, Omar wrote a response titled, 'The Mufti and the moron'. He subsequently formed the House of Ummah, a chat forum for Muslims, and has worked to bring about unity among Muslims, including and especially African Muslims. He publishes a 'communication' whenever he feels it necessary to address an issue in the Muslim community. At the time of writing (December 2020), he had published 160 such communications. The author is on the House of Ummah's mailing list. 


\section{Goolam Vahed}

and has complemented Moulana Desai with his charismatic on-air personality. Based on their common positions on key issues and the use of the same legal team, it is evident that Mufti AK and the Majlis are ideologically aligned to the Jamiatul Ulama Gauteng, which was founded in 2006 with its headquarters in De Deur, Gauteng, under Mufti Hashim Boda, in direct opposition to the existing Jamiat in this province.

These broad, elitist, middle-class groupings do not represent all the Muslims $^{8}$, but they do control the major mosques and institutions. NorthIndian trained or aligned Ulama believe that in the contemporary period, their interpretation of Islam remains the only authentic one. The great Indian scholar, Abu-Hasan Al Nadwi wrote that, while the Muslim world witnessed an intellectual decline from the $15^{\text {th }}$ century, the Muslims of India are an exception:

Though Muslims of India were subjected to the most powerful and culturally vibrant of the Western colonial states, and had the best of their youth drawn to Westernizing institutions, they retained 'a much sharper religious consciousness, a purer Islamic zeal, and a stronger commitment to Islam than did Muslims of other countries' (quoted in Zaman 1999:75).

8 These groupings do not speak for all Muslims in South Africa. There are several independent mosques, one such example being the Claremont Main Road Mosque in Cape Town (cf. Gamieldien 2004). While some African Muslims are part of Indian controlled institutions, others, feeling marginalized, have opted for an independent route, forming the Gauteng Muslim Shura Council (GMSC) in 2014. The GMSC organized the first of what it hoped would be annual conferences of black Muslims in Gauteng from April 19 to 21, 2019. Aslam Fataar, an academic at Stellenbosch University, saw the conference 'by and for Black Muslims as an attempt to establish a line in the sand, to announce and assert the full and autonomous Muslimness of Black Muslims by Black Muslims, and to brook no truck with racism meted out by other groupings. It is, I believe, an assertion of an authentic and autonomous religious identity' (Al-Qalam 2019). The GMSC describes itself as comprising of 'indigenous' Muslims. It remains to be seen how it will develop, given that its numbers are small, and resources limited. The Islamic landscape could also change markedly as new migrants from South Asia and Africa are settling and evolving (cf. Vahed 2021). 
A respected member of the Ulama fraternity, Moulana Abdul Hamid of Gauteng went so far as to state that it is 'fardh [compulsory] to learn Urdu, especially for those Muslims who are connected to the Sub-Continent' (Hamid 2013:12). He explains:

The most important vehicle for us to acquire Deen [faith] is language. A person's culture is associated and directly related with language. Our culture is our Deen, and our Deen is written in the language from which we have our roots in. For us to get the Mizaaj [natural feeling] of our Deen, we will acquire it from our language, and in our case, it is the Urdu language (Hamid 2013:13).

It is worth noting that Persian was the language of the Mughal court in India until the $1860 \mathrm{~s}$, with Urdu replacing it in the late $19^{\text {th }}$ century, and that Moulana Hamid's intellectual forebears, the great Ulama of early $20^{\text {th }}$-century North India, such as Moulana Khalil Ahmad Saharanpuri and Moulana Muhammad Yahya (father of Moulana Zakariyya), wrote their classical works in Arabic to 'demonstrate their mastery of this language as a mark of religious and cultural authority' (Zaman 1999:66). In fact, in the 1850s, Arnold, the Director of Public Instruction in Punjab, wrote that Urdu was 'offensive to a learned Arabic scholar' (Zaman 1999:66). Does insistence on Urdu mean that in the local context the Ummah should comprise exclusively of Indian Muslims or should the local Zulu and Xhosa learn Urdu? (Vahed 2021).

\section{The Nation-State}

The debate over the place of Muslim minorities within a secular democratic state is not peculiar to South African Muslims. As El Fadl pointed out, debate over the role of the Shari'ah in a non-Islamic state is as old as Islam itself:

A growing discourse in Europe and North America focuses on questions of the religious and political status of Muslim minorities. As the historical material indicates, Muslim juridical opinion on these matters is very diverse... There is no Islamic consensus on this issue. What is often overlooked by both Muslims and non-Muslims is this: 


\section{Goolam Vahed}

Diversity of opinion on the status and obligation of Muslim minorities is characteristic not only of the contemporary Muslim community but for the history of Islamic juridical debate; it is not as if some previous clarity or unity of opinion has been lost (El Fadl 1994:129).

During the apartheid era, Moulana Desai of the Majlis decreed that Muslims, living as minorities, were under no obligation to observe the laws of the land if these conflicted with Islamic law, 'unless compelled under coercive oppression' (Haron 2003:58). He further ruled that Muslims could not participate in any 'kuffaar politics': '[T]he prevalence of injustice and oppression does not justify Muslim participation in kuffaar politics... Muslims should not operate under the wing and direction of communists, atheists, and kuffaar in general' (Haron 2003:57). Ebrahim Moosa, a professsor of Islamic Studies, argues that this practice of Islam tends to 'focus on eschatological matters and concern for personal salvation, [and largely ignores] the social and political ethos of Islam' (Moosa 1997:45).

Other Ulama, particularly those who were part of the MJC, participated in anti-apartheid activities through trade unions and political organizations such as the ANC (cf. Esack 1991). Their strand of Islam was 'willing to accept the subordination of Muslim interests in order to establish a broad front against apartheid' (Bangstad \& Fataar 2010:823). In the postapartheid period, the MJC (and by extension, the UUCSA) has adopted a 'loyalist-accommodationist position...in which the comforts and religious freedoms of a minority are seen as best ensured by accommodation with the party in power, [and have shown] uncritical support for the ruling party' (Bangstad \& Fataar 2010:817).

Afsaruddin broadly caricatures the differences in the worldviews of these groupings by describing one group

in an era of increasing globalisation, [as seeking to] interact regularly with people of different faith and cultural backgrounds, [and welcoming] increased opportunities for interfaith and intercultural conversations to facilitate better understanding of one another and to make room for the "Other" in their multicultural and religiously plural environments. [Others, however,] warn of irreconcilable differences in world-views... and attempt to hermetically seal off their cultures from outsiders (Afsaruddin 2015:4). 
With regard to the latter, Ziauddin Sardar writes that there is

one constant present. There is no past and no notion of a different future. But the present exists as an ontological shadow of the past or specifically, the days of the Prophet Muhammad. The history and culture of Muslim civilisation, in all its greatness, complexity and plurality, is totally irrelevant, and to be rejected as deviancy and degeneration (Sardar 2004:13).

Given their different worldviews and approaches to the nation-state, it should come as little surprise that UUCSA and the Majlis/Moulana Desai were in conflict long before the dispute over communal prayers in mosques. They differed over issues such as whether it was permissible for Muslims to participate in secular politics, a proposed Muslim Marriages Bill to regulate Muslim marriages, whether non-Muslims can visit mosques, whether Muslims could consume commercially slaughtered chickens, the efficacy of vaccines, and the entry of women in mosques. Differences came to a head when a PE-based group registered the UUCSA trademark on March 6, 2013 and sent a lawyer's letter to UUCSA on May 27, 2013 to desist from using the name. UUCSA challenged this in court, where the PE group claimed that it had been formed in 1989 with Moulana Desai as ameer (head) and had enacted a constitution that brought UUCSA into being. Judge Tuchten found in April 2017 that there was 'overwhelming' evidence to support the argument that the PE group really wanted to 'steal' UUCSA's identity. The judge pointed to the fact that Moulana Desai had consistently criticized UUCSA as UUCSA, and there was no evidence to suggest that 'UUCSA was an imposter and that he, Mufti Desai, was the authentic representative of UUCSA. On the contrary, Mufti Desai was at pains to distinguish UUCSA from MUSA' (SAFLII 2017:31). The judge declared that the PE group registered the trademark 'UUCSA' mala fide (a 'sustained form of deception').

These simmering tensions came to the fore during the lockdown. 


\section{Goolam Vahed}

\section{The Lockdown and Congregational Worship}

In conjunction with the Islamic Medical Association of South Africa (IMA) and Pathcare (a medical organization), the MJC organized a meeting of Capebased school principals, senior Ulama, Islamic organizations, and medical professionals on March 11, 2020, to decide on a collective response to the pandemic, before President Ramaphosa declared a State of Disaster on March 15, 2020. The MJC issued a five-page statement on March 16, 2020, urging mosques to adhere to the limit of 100 people in congregational prayers, and for worshippers to carry their prayer mats, perform ablution at home, and spend as little time as possible in mosques. Mufti Taha Karaan of the MJC, a graduate of the Darul-Uloom Deoband, stated that 'as long as it is feasible to preserve the performance of congregational prayer in mosques and to preserve life and health, neither should of necessity have to be sacrificed for the sake of the other'. ${ }^{9}$ However, two days later, on March 18, 2020, with cases of the virus increasing, the MJC announced that the Friday Jumu'ah prayer would be suspended for four weeks, and on Sunday March 22, 2020, it called for all mosques to be temporarily closed (Sanglay 2020:1).

This was a bold call given that mosques had never been closed in the 1,400 years of Islamic history, not even during the $14^{\text {th }}$-century Black Death epidemic, and that the Jumu'ah prayer is the one prayer in the week that can only be performed in congregation. Moulana Bham, secretary-general of JUSA, initially announced that congregants in mosques should practice social distance (contrary to the practice of standing shoulder to shoulder), which was 'the only viable solution to containing the pandemic' (Patel 2020). On March 22, 2020, he called on mosques to limit the number of worshippers as Muslims had 'both a religious and civic duty to ensure that we through our actions become part of the solution rather than the problem' (Patel 2020).

The Majlis was critical of these steps. An editorial article titled 'Only Munafiqeen (hypocrites) Cancel Salaat' states that 'it is not befitting for the so-called "Ulama" to have decided to shut down the Masaajid [mosque]'. The Coronavirus had 'truly exposed the munafiqeen, most of whom 'do not never have - truly believed in Allah. Their Imaan (faith) is as flimsy as a cobweb. Their tawakkul [trust in God] is in America' (Aadam 2020). The

9 Mufti Karaan tested positive for Covid-19 in late May 2021 and passed away on June 11, 2021. His brother, Prof Mohammed Karaan, a former dean of Agri Sciences at Stellenbosch University, had died of Covid-19 on January 12, 2021. 
Taleemudeen Islamic Institute of Isipingo Beach, Durban, issued a statement, urging Muslims to continue to pray in congregation in mosques:

After making mashwarah (consultation) with various medical experts as well as taking the opinions of senior counsel advocates, we advise as follows: a) Salaah in the masaajid should not be abandoned but rather be performed in its fixed times; b) Azaan should be called out as usual, and salaah with jamaat should take place (quoted in HOU 2020c).

Some mosques in Durban continued to offer communal prayers until the police stepped in at several mosques on Friday, April 3, 2020. The following day, Zehir Omar attorneys addressed a letter to the government on behalf of MUSA and JUSA 'to request the relaxation of lockdown regulations and the imposition of measures to facilitate the attendance of Muslims at Mosques to observe fundamental worship tenets of the religion of Islam' (HOU 2020a). A group calling itself the Custodians of the Haqq (truth), led by Advocate Zehir Omar, listed 174 mosques that wanted to remain open during the lockdown (HOU 2020a) However, mosques such as Omar Farouq in Lenasia, Merebank, Polokwane Muslim Trust, Hamidia Masjid in Newtown, and Musjidur Rahman in Durban denied giving consent for their names to be used in support of the call. Ismail Omar was of the view that the inclusion of these names 'cannot be accidental. There is thus little doubt that the falsification was the product of intentional manipulation. It is a gross moral travesty that calls for accountability' (HOU 2020a).

Zehir Omar's letter to the President was widely circulated on social media, and various Muslim bodies submitted views opposing the application. The Sunni Ulema Council, Gauteng issued a press statement on April 7, 2020, calling on Muslims 'to hold the larger picture at heart, [respect] the law of the land, [and] not be a component in the spread of the Covid-19 virus' (Sunni Ulema Council 2020). The IMA, the South African Muslim Network, and the Minara Chamber of Commerce submitted a joint letter to the Presidency on April 8, 2020, in which they stated that Zehir Omar's clients 'represent a minute fraction of the total Mosques in SA...We are a Proudly South African community who have rallied and will continue to rise to challenges we all face as a rainbow nation' (IMA 2020). 


\section{Goolam Vahed}

Ebrahim Rasool, who was an official of the anti-apartheid United Democratic Front (UDF) during the apartheid era, and in the post-apartheid period served the ANC in various leadership positions, including as premier of the Western Cape and as South African ambassador to the USA, circulated a hard-hitting social media response:

This is what happens when a radio mufti (Mufti AK), a Muslim tabloid (Majlis), a bogus council (MUSA), and a maverick lawyer (Zehir Omar) converge: They claim rights, but shun responsibility... This is no time for a false unity and solidarity with those knocking a hole in the boat. The mainstream Muslim leadership must speak as one to tell the authorities that the people of the lower deck are a fringe, if vocal, minority; that they are misguided and seek to misguide; that, like all extremists, their extremism is now inert, but as soon as they find a source of power they will unleash destruction (Rasool 2020a).

Feroze Boda took issue with Rasool's use of 'war on terror' vocabulary in this article, asking, 'Is the request for a relaxation on gatherings in the case of masaajid religious extremism?':

For what purpose does he use such labelling? As Muslims, we know very well how such characterisations have been used as a weapon against us...In addition...he assumes incorrectly that his 'mainstream' position is the only acceptable sharia position regarding the forced closure of masaajid...Coupled with the labelling of dissenters as extremists, it allows misplaced nationalism and partisan politics to flourish at the expense of ummah and Islam (Boda 2020b).

Rasool responded on April 17, 2020:

We are dealing with characters biduni taqwa wa adab [without God consciousness or ethical conduct]. Consciousness of God must necessarily curb excesses in conduct, withhold from demeaning even those you differ with, and prevent the use of labels over which only Allah has sovereignty. There is a glossary of labels they have employed against revered, respected fellow ulama [scholars] and 
others with whom they differ...yet, when we call them out, NOT for their belief or disbelief, but for their human utterances or conduct ranging from hate speech to defamation - they protest that we should never use the word EXTREMISM to describe them because of its political consequence of prosecution. Of course there is a misuse by some governments of the label of extremism. But those who identify some people and their actions or their utterances as extremist are not the extremists! The extremists are those who utter hate speech or who use the hate speech and labelling by leaders to transform it into threats (Rasool 2020b).

The President's office responded to Zehir Omar on April 9, 2020, stating that it was unable to 'acquiesce to your demand'. The letter stated that, before approving the lockdown regulations, the President had consulted with religious leaders, including Moulana Bham, secretary-general of JUSA, whose organization, Zehir Omar (misleadingly?) claimed to represent. It added that many Muslim countries had also taken the unprecedented step of stopping congregational prayers and acknowledged that 'being unable to worship at a mosque is a great sacrifice being made by the Muslim community' (HOU 2020c).

Differences between these groupings turned ugly, with various allegations that peddled on social media. Ismail Omar lamented that Muslims were

engaging so much of our community's valuable energy to promote partisan standpoints... We slug it out on our new battlefields in the cyberspace of social media where missiles of denigration explode one after another often in quick succession. And an eager public now immune to this wholly un-Islamic show in town, awaits the next episode. No war is spontaneous, it is leader driven (HOU 2020b).

\section{Congregational Prayer: The Pretoria High Court Decides}

Muhammed Bin Hassim Mohamed, Anas Mohammed Chothia, and the AsSaadiqeen Islamic Centre made an urgent application to the Pretoria High Court to direct the Minister of Cooperative Governance and Traditional 


\section{Goolam Vahed}

Affairs, Dr Nkosazana Dlamini-Zuma, to amend the regulations to allow mosques to remain open during the lockdown, under conditions specified by magistrates. The case was heard before Judge Brenda Neukircher on April 23, 2020.

Appearing for the applicants, Advocate Boda argued that the lockdown regulations unjustifiably limited his clients' constitutional rights to freedom of movement, religion, association, and dignity. Muslims were obliged to pray in mosques in congregation, he argued, and 'criminalization' of congregational prayer compelled them to disobey their religion and took away their right to a dignified life source. Boda submitted that the state was thus placing the applicants in a Hobson's choice of either disobeying their religion or the state (SAFLII 2020:parr $26 \& 27$ ). The application also proposed that the Coronavirus was not contagious. An affidavit dated March 29, 2020, from Mufti Mohammad Abdussalaam Chatgari of Bangladesh, stated that the revealed Islamic texts were explicit that there was no contagion of disease. The affidavit was categorical that "no consideration is given to (medical) research when it conflicts with the Noble Qur'an and hadith. Their research is limited to their intellect, which is of the level of doubt. The information in the Noble Qur'an and hadith is based on divine revelation' (SAFLII 2020). Since the disease is not contagious, the argument went, social distancing and the closure of mosques were unnecessary.

The state argued that section 36 of the Constitution permitted the limitation of citizens' rights if it was justified, and that this was the case because the lockdown aimed to preserve every citizen's right to life, health care, and dignity in light of the threat posed by the Coronavirus. Prohibition of congregational prayer was a necessary, though 'painful' limitation necessitated by the pandemic. The state contended that it would not be practical to grant permission for applicants to attend mosques under exceptional conditions as it could not regulate every place of worship.

Though not directly involved in the court case, UUCSA ${ }^{10}$ applied to be an amicus curiae in the matter. A statement on its website, dated April 24, 2020, explained that it got involved to dispel

10 The Durban-based Women's Cultural Group was the second amicus curiae. It focused on the health risks posed to women and children in the event that men could pick up the virus at the mosque, and further stated that in the event of the 
the potentially dangerous notion that the Muslim Community as a whole was taking the government to court [in order to avoid] strained relations with the government which has been emphatically proud of its long and shared history with Muslims. [UUCSA's involvement] counters the negative stereotyping that has inevitably resulted from a part of our community seeking a type of exceptional treatment over 60 million other citizens. We are not different to our fellow citizens and we must stand with them, now more than ever. [While UUCSA opposed] unfettered restriction of our (Muslim) rights, [it accepted] restrictions in the appropriate context. We must not forget our obligations to society and our responsibility to avoid harm to others. Islam enjoins us to do so (UUCSA 2020).

UUCSA agreed that the virus was contagious, and that Muslims were permitted to offer their prayers at home since the limitations on congregational worship were temporary. Given that the restrictions were 'directed towards the safeguarding of individual and societal health, access to healthcare, the preservation of life and facilitating an environment in which to achieve this, the measures enacted by Government are reasonable and justifiable' (UUCSA 2020).

In an hour-long broadcast on Markaz Sahaba, 'Keep our Masajids open', on April 19, 2020, Mufti AK argued that UUCSA's opposition to the application was based on a 'personal vendetta' against him (20 percent) and Moulana Desai (80 percent). UUCSA's aim, he said, was to 'curry favour with government. They have perks, diplomatic passports, etc, and can't give it up. In Muslim countries grand muftis are paid thousands of grands, so give any fatwa necessary...same thing is happening in South Africa. We will expose them' (Hoosen 2020a). The Mufti pronounced that UUCSA was 'out of the fold of Islam. There were two parties in South Africa, and only one was determined to defend Islam and follow in the way of the sahaba [companions of the Prophet]' (Hoosen 2020a).

Immediately after the case ended on April 23, 2020, with judgment reserved, Attorney Zehir Omar told interviewers on Laudium Today television channel that Muslims should defy lockdown regulations and pray

application being successful, no provision was made in it for women to be allowed to pray in mosques. 


\section{Goolam Vahed}

in congregation in mosques and that he would defend without cost anyone who was arrested. The Economic Freedom Fighters (EFF), a Black nationalist opposition political party in South Africa, sought to make political capital of the issue. Its treasurer general, Omphile Maotwe, pressed charges at the Pretoria Central Police Station on April 27, 2020 for Omar to be struck off the attorney's roll for encouraging people to break the law. Maotwe warned that if Omar was not arrested, the police 'will be directly provoking us to make a community arrest' (SABC News 2020). However, Omar later made an about-turn and issued a statement that he 'never told the public to disobey the law' and called on Muslim South Africans to abide by the lockdown regulations and worship from their homes, as they awaited the High Court ruling (SABC News 2020).

As has been its practice since its formation, the EFF was eager to exploit anti-Indian sentiments among its supporters. On March 19, 2020, shortly after the lockdown was announced, a certain Ahmed Saeed posted a Facebook advert (screenshot received by author on WhatsApp) that his religious school in Lenasia would be holding the Friday prayer with 'no restrictions' (quoted in Vadi 2020). EFF leader, Julius Malema posted Saeed's message on his Twitter account with the remark, 'You see now' (Vadi 2020). His supporters followed with provocative comments that reflected Islamophobia and anti-Indianism, like, 'Mr Malema, don't start with Muslims. They'll bomb our whole country to ashes, they don't mind dying for Allah these ones! Please!' (Vadi 2020); 'Jamnadas must take his people and leave Mzansi' (Vadi 2020), and 'Islam is the world's biggest problem! Coronavirus is nothing to compare these assholes' (Vadi 2020). While Saeed backtracked, both Malema's racial baiting and his supporters' racial rhetoric, including attacking Minister Pravin Gordhan (Jamnadas), who is an Indian South African but not a Muslim, underscored the potential dangers of this populist racial nationalism (cf. Desai \& Vahed 2019:330-349).

The application was dismissed by Judge Brenda Neukircher on April 30, 2020. The judge took heed of UUCSA's submission that

when considered in appropriate context, the applicants (and all Muslims) would be complying with the objectives of Islamic law by adhering to the lockdown regulations, despite the pain experienced by the temporary separation from the mosque. This is because of the importance Islam places on the sanctity of the life and dignity and 
health of the broader community in the interests of common good over the embellishment of the prayer of an individual Muslim. They submit that the limitations on congregational prayer in a mosque, during the time of a pandemic, are a practical manifestation of this and are reflective of the opinion of the majority of Muslim scholars across the world (SAFLII 2020:par 49).

According to the judgment, the application was

not about whether the applicants are correct in their interpretation of their religious doctrine. It is also not about whether they are true in their beliefs. What this application is about is whether or not regulations...issued under the Disaster Management Act are reasonable and justifiable in the circumstances under which they were promulgated (SAFLII 2020:par 4).

The judge acknowledged the difficulty experienced by Muslims, but noted that all religious groups were equally affected and had been called upon to make sacrifices "in the name of "the greater good", the spirit of "ubuntu"...in ways that impact on their livelihoods, their way of life and their economic security and freedom' (SAFLII 2020:par 14). The judge further argued that it was not practical to grant special dispensation to mosques as it would be impossible to regulate them:

There are at least 850 mosques throughout South Africa. Add to this the number of churches, temples, synagogues and other places of worship, there are untold numbers of persons who will be moving to and from their residences each day and who will be praying in congregations. Social distancing, imperative in assisting to flatten the curve will be, if not impossible to enforce, then nigh on impossible as human nature is not suited to the severely restrictive obligations that social distancing has thrust on society so suddenly. Making allowances of the nature sought, would be tantamount to opening the floodgates (SAFLII 2020:par 68).

Judge Neukircher found that the respondents had shown that the measures were 


\section{Goolam Vahed}

rational [in order to help] achieve their objectives of stemming or eradicating the COVID-19 pandemic; [in the view of the court,] if regard is had to the sacrifices that have had to be made, they cannot ask that exceptions be made of the nature sought. [The judgment concluded,] I cannot find that the restrictions imposed are either unreasonable or unjustifiable and thus the application must fail (SAFLII 2020:par 77).

\section{Fragmentation and Realignment}

When it became clear that the country would be subjected to an extended lockdown, religious leaders asked the Presidency to reconsider the prohibition on congregational worship. In a 'public appeal' on its website on May 19, 2020, Moulana Bham's JUSA called on worshippers to 'pray not only for a positive outcome that can see us return to our beloved masaajid but also that the Almighty lifts away this pandemic from the midst of humanity, altogether' (Bham 2020). Religious leaders met with President Ramaphosa and the Cooperative Governance Minister, Dr Dlamini-Zuma on May 20 and 25, 2020. Ramaphosa announced that the National Coronavirus Command Council had acceded to proposals by religious leaders and that when the country moved to Level 3 of the Covid-19 lockdown on June 1, 2020, recognized places of worship could resume public services subject to the strict norms and standards set out in the regulations, including social distancing and the wearing of masks (Nicolson 2020).

Many ordinary South Africans were aghast at the concession to places of worship, while places of business remained closed. In the online comments following Nicolson's article, a certain Robert Ross commented that 'the restaurants, sporting facilities, gyms, hairdressing and beauty salons and countless other community services are, at this point, much more essential than an open church building' (Nicolson 2020). Ingrid Obery wrote that 'organised religion is not essential, so this is about money and votes. The government's time should rather be spent on truly essential issues such as feeding the starving, making the health system work properly, creating an enabling environment for job creation' (Nicolson 2020). David Bertram commented that 'if you are doing this then you need to open up the entire economy' (Nicolson 2020). A Peter Doble described the decision as 'one of 
the most idiotic unjustifiable pronouncements in the lockdown saga. One rule for them: Another for the rest' (Nicolson 2020).

The Majlis newspaper issued a fatwa (ruling) on June 4, 2020, that it was haram (forbidden) to perform prayer with a mask on or practice social distancing. Some mosques opted not to open until the danger of the pandemic had passed. The MJC, for example, advised mosques on May 28, 2020, to 'delay opening their doors for congregational prayers for at least another month' (Dante 2020). Imam Rashied Omar of the Claremont Main Road Mosque in Cape Town told interviewer Lester Kiewit on Cape Talk Radio on May 28, 2020, that in not reopening the mosque, 'we were guided by one of the supreme objectives of our faith...the preservation, sanctity, and reverence of life' (Kiewit 2020). Mosques under the jurisdiction of UUCSA that opened, generally adhered to government protocols while those falling under the broad banner of the Majlis/Mufti AK, did not enforce regulations regarding social distancing, the wearing of masks, and limits on numbers, but allowed those who wished to social distance and wear masks to do so. While introducing guidelines, the government never showed an inclination to enforce them.

The court case led to a realignment of authority among Muslims. Ulama who supported or at least were ideologically aligned to the Majlis/Mufti AK position, formed a new organization called the Wifaqul Ulama Southern Africa on June 24, 2020. 'Wifaqul' means 'mutual agreement', and according to its proclamation, the organization aimed to provide 'clear Shar'ì guidance in matters of Dīn in an era of escalating trials, tribulations and challenges' (Wifaqul Ulama South Africa 2020). Wifaqul Ulama aimed to 'preserve and promote the Deen in our country in its pure and pristine form' (Wifaqul Ulama South Africa 2020). Wifaqul's leadership controlled Darul Ulooms in places like Camperdown, Isipingo, Estcourt, Port Shepstone, PE, Newcastle, and Azaadville, as well as leading mosques in KwaZulu-Natal and Gauteng. On November 1, 2020, an organization calling itself the Association of Muslim Professionals of South Africa (AMPSA), was formed, with Advocate Feroze Boda, who had led the application for the opening of mosques, as a founding member. It was allied to Wifaqul, and its aims included 'draw[ing] attention to, and remain[ing] vigilant against, any misrepresentations or distortions of the teachings of Islam, or any attempt to compromise the Shari'ah' (AMPSA 2020). 


\section{Goolam Vahed}

The Wifaqul Ulama constitutes a direct ideological opposition to UUCSA. While not formally associated, there is a broad alignment between it and the Majlis/Mufti AK faction. When Mufti AK was asked about this organization on his program, 'Bliss of Marriage' on Markaz Sahaba on June 24, 2020, he stated:

They are authentic. I saw the long list of Ulama, I know each one of them. Because of what has happened in the past three months, six months, and for years also. This is a vote of no confidence in the previous Ulama...[Wifaqul Ulama] is 100 percent authentic and we make dua [invocation] for them that Allah use them for the protection of Ahlus-Sunnah-Wal-Jama'ah, InshaAllah [God willing]. We know what their views are regarding Shiahs and so forth...so, yes, it is authentic (Hoosen 2020b).

\section{Conclusion}

South Africans' notions of deprivation were different under the lockdown. Vulnerable workers were forced to work in the mines and supermarkets while many among the middle classes challenged lockdown regulations when their lifestyles, religious and cultural practices, and economic wellbeing were affected. The legal challenge over congregational prayer was one such application. In weighing up the individual freedoms recognized in the Constitution against the broader public good, the judiciary came down on the side of the public health good.

Just as the pandemic underscored the profound economic and racial divide in the country, the application for congregational prayer in mosques exposed the deep divide among Muslims. The applicants who wanted mosques to remain open were in all likelihood aware that they had little chance of success. However, they won a huge victory in the court of Muslim public opinion by presenting themselves as the 'defenders' of the faith. In this contestation for authority among Muslims, 'the capacity to impose one's point of view as the authoritative one has become crucial. Directly at stake is power, its conquest, and its conservation' which, in turn, determines the kinds of resources to which religious figures have access (Dupret 2018:217). The application hardened divisions among Muslims. 
More broadly, the court case raised the question of how Muslims should live in a secular democracy. Whereas the Majlis grouping was once considered a fringe group among Muslims, its approach to the secular state is now being embraced by many. The regular discourses from some Ulama that the pandemic is an elaborate hoax ('convid', as one moulana repeatedly described it) initiated by big pharma, or that the vaccine is part of a plot by Bill Gates to initiate a global surveillance scheme, that lockdown measures are an assault on Islam in South Africa, or that these measures mark the arrival of the Dajjal (equivalent to the anti-Christ, which has set in motion the struggle between good and evil until the end of the world), have contributed to deep distrust of the state, and challenged the previously positive attitudes of many Muslims towards it (cf. Vahed 2021).

Most Muslims in the post-apartheid period were content that they could practice their religion freely in South Africa, unlike places like Western Europe, North America, and Australia, where Islamophobia is visceral and Muslims are 'othered' as extremists and terrorists. At the completion of this article (June 2021), many European leaders are spouting narratives of the Muslim 'enemy within'. Some, like French President, Emmanuel Macron, are taking steps to shut down mosques, accusing Muslims of fostering 'separatism', while others have banned minarets. The head scarf is also banned in some countries, while Denmark requires children to spend time away from their parents each week to teach them 'Danish values'. Cesari (2016:235) coined the term 'securitization paradigm' to refer to Western countries' policy of suspending the 'normal rule of law' to institute measures that aim to 'Europeanise' Muslims who are regarded as an 'existential threat to European and American political and secular order'. Similar narratives are played out in China, Israel, Myanmar, and India. Some countries have initiated schemes to train Imams domestically and only allow the employment of graduates from Western Islamic Studies university programs (Groeninck \& Boender 2020; Hashas 2018; Schmid 2020).

Changing Muslim practices and beliefs in South Africa, a heightened sense of being Muslim due to global events, and aspects of state policy such as the recognition of gay marriages, the introduction of sex education in schools, and the steps taken to curb the spread of the Covid-19 pandemic, have generated feelings of distrust of the state among Muslims. To this we can add the proposed Promotion of Equality and the Prevention of Unfair Discrimination Amendment Bill which, opponents of the Bill believe, will 


\section{Goolam Vahed}

seriously impact their constitutional rights to freedom of religion, belief, and opinion, and threaten the autonomy of religious organizations to determine their own doctrine and beliefs, free from interference by the State, as well as a proposed Omnibus Marriage Bill which contains provisions that go against the Shari'ah (Islamic Law). Some Muslims believe that South Africa is taking the first steps on a road traveled by some of the European countries. What trajectory will the current rhetoric, disputation, argumentation, and contestation among Muslims take? Will the vitriol against other Muslims continue? Will anti-state discourse intensify? And, if so, will the South African government feel compelled to intervene in similar manner to places like Europe, China, India, and Australia?

South African Muslims do not obey the rulings of one Islamic authority. While this allows more voices to be heard and debates to occur, it has led to a doctrinal war within the Muslim community that, as this article has vividly demonstrated, is filled with invective and hatred. In a context of increasing fragmentation among Ulama, many are aggressively pushing their version of an 'authentic' Islam through the pulpit and various social media platforms, while demonizing those who hold alternative views.

The debate over mosque attendance during Covid-19 brought to the fore these deep divisions. The coming of vaccines in 2021 further inflamed these tensions, as some Ulama threatened legal action if it was made mandatory. That fell flat as the vaccines are optional. So it goes. In his Prison Notebooks, Antonio Gramsci wrote, 'The crisis consists precisely in the fact that the old is dying and the new cannot be born; in this interregnum a great variety of morbid symptoms appear' (Gramsci 1971:275-276). It appears to be that time among Muslim South Africans. The morbid symptoms include such things as the demonization of Ulama, labeling anyone who holds a contrary view as a kaafir (non-believer), and the issuing of fatwas based on ideology. Perhaps this is how all religions unfold and return to the fold, as authority and authenticity are questioned and reasserted.

The masks are off, social distancing between Muslim factions is increasing, and the fight for authority is one of the most fiercely contested phenomena among Muslims in contemporary South Africa. 


\section{References}

Aadam, M.H.I. 2020. Only Munafiqeen cancel Salaat. Majlis, March 28, 2020. Available at: https://www.themajlis.co.za/index.php?option= com_content\&view=article\&id=1871:munaafiqeen-cancel-salaat\& catid=34:majlis-articles\&Itemid=27. (Accessed on April 25, 2020).

Afsaruddin, A. 2015. Contemporary issues in Islam. Edinburgh: Edinburgh University Press.

Al-Qalam. 2019. Black Muslim indaba sparks debate. Al-Qalam. February 8, 2019. Available at: http://alqalam.co.za/black-muslim-indaba-sparksdebate/. (Accessed on July 2, 2020.)

AMPSA (Association of Muslim Professionals of South Africa). 2020. AMPSA launch statement. November 1, 2020. Electronically submitted on behalf of AMPSA Shura Council. WhatsApp message. (Accessed on November 3, 2020.

Bangstad, S., \& A. Fataar 2010. Ambiguous accommodation: Cape Muslims and post-apartheid politics. Journal of Southern African Studies 36, 4: 817-831. doi: 10.1080/03057070.2010.527639

Bano, M. 2019. Introduction. In Bano, M. (ed.): Modern Islamic authority and social change. Vol 2: Evolving debates in the West. Edinburgh: Edinburgh University Press.

Bham, E. 2020. Call for government to review restrictions on religious congregations: A JUSA PUBLIC APPEAL. Jamiatul Ulama. May 19, 2020. Available at: https://jamiatsa.org/call-for-government-toreview-restrictions-on-religious-congregations-a-jusa-public-appeal/.

(Accessed on March 15, 2021.)

Blunt, G.R. 2018. Hashtag Islam: How cyber-Islamic environments are transforming religious authority. Charlotte: University of North Carolina Press.

Boda, F. 2020. Is the request for a relaxation on gatherings in the case of masaajid religious extremism? A response to brother Ebrahim Rasool. WhatsApp message. (Accessed on April 6, 2020.)

Boda, F. 2020b. Why the 'war on terror' vocabulary? WhatsApp message. (Accessed on April 10, 2020.)

Cesari, J. 2016. Securitization and Secularization: The two pillars of state regulation of European Islam. In Haynes, J. (ed.): Routledge Handbook of Religion and Politics. New York: Routledge. 


\section{Goolam Vahed}

Dante, Z. 2020. MJC calls for deferral of Masajid opening, or extreme caution in compliance with safety regulations. May 28, 2020. Available at: https://mjc.org.za/2020/05/28/mjc-calls-for-extreme-cautionand-compliance-with-safety-regulations-when-opening-masajid/. (Accessed on June 30, 2020).

Desai, A. \& G. Vahed 2019. A history of the present: A biography of Indian South Africans, 1994-2019. New Delhi: Oxford University Press.

Dupret, B. 2018. What is the Sharia? London: Hurst.

El Fadl, K.A. 1994. Legal debates on Muslim minorities: Between rejection and accommodation. The Journal of Religious Ethics 22, 1: 127-162.

Esack, F. 1991. Three Islamic strands in the South African struggle for justice. Third World Quarterly 10, 2: 473-498.

Gamieldien, F. 2004. The history of the Claremont Main Road Mosque, its people and their contribution to Islam in South Africa. Claremont, Cape Town: Claremont Main Road Mosque.

Gramsci, A. [1930] 1971. Selections from the prison notebooks, 'Wave of materialism' and 'Crisis of authority'. New York: International Publishers.

Groeninck, M. \& W. Boender 2020. Introduction to special issue on exploring new assemblages of Islamic expert education in Western Europe. Religions 11, 6. 12 pages. doi: https://doi.org/10.3390/rel110 60285

Hamid, M.A. 2013. A discourse by Fakrul Ummat Abdul Hamid Ibn Ibrahim Is 'haq Sahib. Azaadville: Akhtari.

Haron, M. 2003. Maulana Ahmad Sadeq Desai and his Majlis: An ultraconservative voice in the Eastern Cape wilderness. Annual Review of Islam in South Africa 6: 55-59.

Hashas, M. 2018. The European Imam: A nationalized religious authority. In Hashas, M., J.J. De Ruiter, \& N.V. Vinding (eds.): Imams in Western Europe: Developments, transformations, and institutional challenges. Amsterdam: Amsterdam University Press.

Hoosen, A.K. 2020a. Report back - latest developments regarding the opening of Masajid. April 19, 2020. Available at: https://markaz sahaba.com/site/mufti-ak-hoosen-lectures-special-shows-and-tours/. (Accessed on April 24, 2020.) 
Hoosen, A.K. 2020b. Bliss of marriage. Part 2. June 24, 2020. Available at: https://markazsahaba.com/site/msor-bliss-of-marriage/. (Accessed on June 25, 2020.)

HOU (House of Ummah). 2020a. Communication 138: When is Haqq not Haqq? May 5, 2020. Available at: https://www.tapatalk.com/groups/ houseofummah/communication-138-when-is-haqq-not-haqq-t223. html. (Accessed on May 20, 2020.)

HOU (House of Ummah). 2020b. Communication 142: Those were the days when Jamiats were Jamiats. June 10, 2020. Available at: https:// www.tapatalk.com/groups/houseofummah/communication-142those-were-the-days-when-jamiats-t227.html. (Accessed on May 20, 2020.)

HOU (House of Ummah). 2020c. Communication 127: Satyagraha is not necessary. March 26, 2020. Available at: https://www.tapatalk.com/ groups/houseofummah/communication-127-satyagrahah-is-notnecessary-t212.html. (Accessed on April 26, 2020.)

IMA (Islamic Medical Association of South Africa), South African Muslim Network (SAMNET), and the Minara Chamber of Commerce. 2020. Response to Attorney Zehir Omar's letter regarding the opening of mosques for congregational prayers. April 8, 2020. WhatsApp message. (Accessed on April 9, 2020.)

Jeppie, S. 2007. Language, identity, modernity: The Arabic study circle of Durban. Pretoria: HSRC Press.

Kiewit, L. 2020. 'We were guided by a supreme objective of our faith - the preservation, sanctity and reverence of life,' says Imam Rashied Omar. Cape Talk Radio. May 28, 2020. Available at: https://www.capetalk.co.za/articles/385101/why-claremont-mosquewon-t-reopen-we-revere-life-and-assessed-the-risk?ref=pid:111. (Accessed on June 5, 2020.)

Koch, J. 2017. South Asian Muslim women on the move: Missionaries in South Africa. South Asian Diaspora 9, 2: 1-18. doi: 10.1080/ 19438192.2017.1335471

Moosa, E. 1997. Worlds 'apart': Tablighi Jama'at in South Africa under apartheid, 1963-1993. Journal for Islamic Studies 17: 28-48.

Moosa, E. 2015. What is a Madrasa? Chapel Hill: University of North Carolina Press. 


\section{Goolam Vahed}

Nicolson, G. 2020. Religious services to resume under Level 3, but limited to 50 people. Daily Maverick. May 26, 2020. Available at: https://www.dailymaverick.co.za/article/2020-05-26-religiousservices-to-resume-under-level-3-but-limited-to-50-people/\#gsc.tab= $\underline{0}$. (Accessed on June 29, 2020.)

Official Site of Mufti AK Hoosen. 2018. Welcome to the official site of Mufti AK Hoosen. Available at: https://muftiakhoosen.net/. (Accessed on April 20, 2021.)

Patel, F. 2020. Jamiat SA calls for suspension of congregations at all Masaajid. Radio Islam. March 22, 2020. Available at: http:// radioislam.org.za/a/index.php/latest-news/28053-jamiat-sa-calls-forsuspension-of-congregations-at-all-masaajid-in-light-of-coronavirusspread-in-sa.html. (Accessed on May 11, 2020.)

Rasool, E. 2020a. 'Stop the people of the lower deck - Coronavirus will NOT be spread from the mosques!' April 6, 2020. WhatsApp message. (Accessed on April 7, 2020.)

Rasool, E. 2020b. Combatting the three pandemics of our time: Covid-19, extremism and Islamophobia. April 17, 2020. WhatsApp message. (Accessed on April 18, 2020.)

SABC News. 2020. EFF wants attorney Omar arrested for violating lockdown regulations. April 27, 2020. Available at: https:// www.sabcnews.com/sabcnews/eff-wants-attorney-omar-arrested-forviolating-lockdown-regulations/. (Accessed on July 2, 2020.)

SAFLII (South African Legal Information Institute). 2017. United Ulama Council of South Africa v United Ulama Council of South Africa and Another (Case No. 50187/16), ZAGPPHC 154. March 24, 2017. Available

at: http://www.saflii.org/za/cases/ZAGPPHC/2017/154.html. (Accessed on May 9, 2020.)

SAFLII (South African Legal Information Institute). 2020. Mohamed and Others $\mathrm{v}$ President of the Republic of South Africa and Others (21402/20) [2020] ZAGPPHC 120; [2020] 2 All SA 844 (GP); 2020 (7) BCLR 865 (GP); 2020 (5) SA 553 (GP). April 30, 2020. Available at: http://www.saflii.org/za/cases/ZAGPPHC/2020/120. html. (Accessed on May 9, 2020.)

Sanglay, M. 2020. Covid-19. South Africa rallies to president's call. Muslim Views 34, 3: 1-2. 
Sardar, Z. 2004. Desperately seeking paradise: Journeys of a sceptical Muslim. London: Granta Books.

Schmid, H. 2020. I'm just an Imam, not Superman: Imams in Switzerland. Between stakeholder objects and self-interpretation. Journal of Muslims in Europe 9, 1: 64-95.

Schoeman, W.J. 2017. South African religious demography: The 2013 General Household Survey. HTS Teologiese Studies/Theological Studies 73, 2.7 pages. a3837. doi: https://doi. org/10.4102/hts.v73i2. 3837

Sitoto, F.T. 2014. Communication 18: On the House of Ummah initiative: Emerging thoughts. House of Ummah. June 26, 2014. Available at: http://houseofummah.lefora.com/topic/75/COMMUNICATION-18INDIAN-RADAR-INTERACTIVE-MEETINGS\#.V78a5k3r3IU. (Accessed on August 26, 2016.)

Sunni Ulema Council, Gauteng. 2020. Press release: Adherence to the lockdown. April 7, 2020. WhatsApp message. (Accessed on April 9, 2020.)

Tayob, A. 1999. Islam in South Africa: Mosques, Imams, and sermons. Gainesville: University of Florida Press.

Tayob, A. 2004. Race, ideology and Islam in contemporary South Africa. In Feener, R.M. (ed.): Islam in world cultures. Santa Barbara: ABCCLIO.

United Ulama Council of South Africa (UUCSA). 2020. UUCSA statement on the High Court proceedings on the closure of all religious places of worship. April 24, 2020. Available at: http://uucsa.co.za/index. php/publications/covid-19/124-proceedings-of-the-high-courtchallenge-on-the-closure-of-all-religious-places-of-worship. (Accessed on May 10, 2020).

Vadi, I. 2020. SA faith communities and Covid-19: Between religious belief and political idiocy. Daily Maverick. March 23, 2020. Available at: https://www.dailymaverick.co.za/article/2020-03-23-sa-faithcommunities-and-covid-19-between-religious-belief-and-politicalidiocy/. (Accessed on March 30, 2020).

Vahed, G. 2000. Indian Islam and the meaning of South African citizenship a question of identities. Transformation 43: 25-51. 


\section{Goolam Vahed}

Vahed, G. 2003. Contesting 'orthodoxy': The Tablighi-Sunni conflict among South African Muslims in the 1970s and 1980s. Journal of Muslim Minority Affairs 23, 2: 315-336.

Vahed, G. 2021. Muslims in post-apartheid South Africa: Race, community, and identity. Social Identities: Journal for the Study of Race, Nation, and Culture 27, 1: 44-58. doi: 10.1080/13504630.2020.1814724

Vawda, S. 2017. Migration and Muslim identities: Malawians and Senegalese Muslims in Durban, South Africa. Journal for the Study of Religion, 30, 2: 32-74.

Wifaqul Ulama South Africa. 2020. About us. June 24, 2020. Available at: https://wifaq.org.za/?page_id=2. (Accessed on June 30, 2020.)

Zaman, M.Q. 1999. Commentaries, print and patronage: 'Hadīth' and the Madrasas in Modern South Asia. Bulletin of the School of Oriental and African Studies, University of London 62, 1: 60-81.

Zaman, M.Q. 2010. The Ulama in contemporary Islam: Custodians of change. Princeton: Princeton University Press.

Prof Goolam Vahed

Department of History University of KwaZulu-Natal vahedg@ukzn.ac.za 